Arne T. Kofoed

\title{
ASIAN DRAMA
}

An. Inquiry into the Poverty of Nations.

Gunnar Myrdal.

Pelican Book 1968, 2284 sider, pris ca. $90 \mathrm{kr}$.

Asian Drama er et kæmpemæsigt værk på mere end 2000 sider. Det tog den for statskundskabstuderende så velkendte Gunnar Myrdal og hans assistenter ti a r at skrive bogen.

Asian Drama er et trebindsvark, der er opdelt $\mathbf{i}$ syv dele og 16 appendikser. De syv dele behandler hver for sig betydningsfulde sider ved den sydasiatiske virkelighed, medens de 16 appendikser især beskæftiger sig med mere teoretiske og tekniske problemer ved studiet af Sydasien, of te ret snævre, statistisk-økonomiske overvejelser.

\section{Asian Dramas emne og værdipræmisser.}

Myrdals udgangspunkt er at skrive en generel bog om den aktuelle situation i sydasien, fremtidsudsigterne $i$ udviklingsmasig henseende og de alternative politiske muligheder, som de nationale regeringer star overfor. Det er altsa udviklingsproblematikken, der er $i$ focus. Dog har bogen fået en ret stærk metodologisk drejning, fordi Myrdal mere og mere fandt, at de herskende (især okonomiske) begreber og teorier var uanvendelige uden for de vestlige lande, nye problemstillinger matte opstilles etc.

Ved Sydasien forstar Myrdal: Indien, Pakistan, Ceylon, Burma, Malaya, Thailand, Indonesien og Philippinerne. Det kan dog med det samme slás fast, at Asian Drama hovedsageligt beskæfiger sig med indiske forhold.

Sin videnskabsopfattelse tro gor Myrdal rede for sine værdipræmisser. Han arbejder med et sæt, han kalder moderniseringsidealerne. De består af rationalitet, plan- 
lagning for udvikling, stigning i levestandard, social og okonomisk lighed, forbedrede holdninger og institutioner, national konsolidering, national uafhangighed, politisk demokrati (er ikke nodvendigt for at fá de andre idealer opfyldt), nærdemokrati og social disciplin. Hans hovedpræmisser er rationalitet og planlægning. Myrdal arbejder altså med rent vestlige værdipræmisser. Valget af disse legitimeres ved, at eliten $i$ sydasien har gjort dem til sine egne. Der er desuden ingen vej tilbage.

Approach.

Analyser af udviklingsproblematikken er blevet foretaget på mange forskellige mader, normalt med vægten lagt på de rent okonomiske faktorer. Myrdal anvender en institutionel approach. Som det centrale ved denne ser han:

"-- that history and politics, theories and ideologies, economic structures and levels, social stratification, agriculture and industry, population developments, health and education and so on, must be studied not in isolation but in their mutual rela-

En sadan approach svarer til den máde Adam Smith og Karl Marx angreb okonomiske problemer p\&. Undertitlen hentyder da ogsá til Adam Smith's hovedvark. Fremgangsmáden svarer vel ogsa til gængs sociologisk metode.

Det kendetegnende for den institutionelle approach er, at der lægges vægt pá, at ingen problemer er rent okonomiske, men at de $\mathrm{ma}$ ses $i$ deres politiske og sociale sammenhang. I Vesteuropa er dette ikke sa stort et problem, fordi man oftest kan regne med en automatisk tilpasning af disse forhold til den okonomiske udvikling. I Sydasien er den basale okonomiske og sociale struktur så forskellig fra Vesteuropas, at det som et forste skridt er nodvendigt med en forståelse af denne. Hertil er en bred approach nødvendig. Ved hjælp af denne påiser Myrdal hele bogen igennem, at den hidtidige forskning af udviklingsproblematikken arbejder med inadækvate og ofte helt misvisende begreber, idet den

1) Asian Drama p. $x$. 
direkte har anvendt vestlige økonomiske modeller på sydasiatiske forhold uden hensyntagen til de fundamentalt forskellige omgivelser.

Teori.

I overensstemmelse med sin approach opstiller Myrdal en tentativ, generel og social teori om underudvikling. Myrdal ser hvert land som et socialt system, der består af et antal elementer. Disse kaldes vilkar (conditions). Der er total interdependens mellem dem. Ingen af dem kan siges at være mere betydningsfulde end andre. De seks vilkăr er:

1. Produktion og indkomster.

2. Produktionsforhold.

3. Levestandard.

4. Holdninger til liv og arbejde.

5. Institutioner.

6. Politik.

At ingen af disse har storre betydning end andre, har Myrdal svært ved at holde fast ved i fremstillingen; især lægger han megen vægt $p \&$, hvor betydningsfuld en ændring af institutioner og politik er.

Begreberne underudvikling og udvikling defineres ud fra dette skema. For at fa en kumulativ udvikling igang, må der sættes samlet ind på en påvirkning af de fem forste vilkår ved benyttelse af vilkar seks. Dette kræver en vældig indsats, fordi de alle er meget træge. Man taler om ligevægt på et lavt niveau.

Gennemgang af Asian Drama.

Forste bind omhandler dels en historisk, dels en okonomisk-statistisk beskrivelse af området. Disse er måske de mindst interessante $i$ værket, idet der her ikke siges meget mere, end man kan lase $i$ ethvert standardværk på omradet. Dog er der nogle interessante afsnit om disse landes placering $i$ den internationale handel. Myrdal ser disse lande som meget ilde stedt her. En indskrænkning af handelen med udlandet, især de vestlige lande, er nødvendig. En 
øget regional samhandel ville vare onskelig, men den er ikke særlig sandsynlig.

Andet bind er meget vægtigt. Her diskuteres de ideologiske, politiske og institutionelle aspekter ved planlægning og mere specifikt okonomisk planlægning. Hovedkonklusionen pá afsnittet om den ikke-specifikt okonomiske planlægning er, at vel udtaler den herskende elite sig tidligt og silde pa et socialistiskmodernistisk grundlag (altsa $i$ overensstemmelse med Myrdals præmisser), men at alt dette er blot og bar retorik. Næsten intet gores for at nedbryde de udviklingshæmmende institutioner og holdninger til liv og arbejde. De politiske institutioner er svage. Myrdal taler om en "soft state". Dette er et begreb, Myrdal indforer til at beskrive et samfund med en ringe grad af social disciplin. Der stilles fá forpligtelser til befolkningen, og de fá, der stilles, gennemtvinges kun $i$ ringe grad. Dette er noget af det centrale i udviklingsproblematikken: at fa en kumulativ udviklingsproces igang kræver en stærk statsmagt. Hvordan skaber man en sadan?

Afsnittet om den mere specifikt okonomiske planlægning er vel det mest originale $i$ bogen. Her lægger Myrdal i sin analyse vagt $p \mathfrak{d}$ det menneskelige aspekt: at det er mennesket og dets arbejde, der ligger bag al udvikling. Her ser man virkelig Myrdals arbejdsmetode og fordelene ved at anvende den institutionelle approach. Myrdal nedbryder det herskende begrebsapparat på området og foresiar et nyt. Dette anvendes derefter på de problemer, der er under overvejelse. Foruden at dette afsnit er originalt, behandler det ogsa de problemer, der er mest afgorende for planlægning af udvikling, nemlig hvordan produktionen kan forøges. Dette ses ikke fra et capital/output synspunkt, men fra et labour/output. Fordelen ved at analysere produktionsprocesserne ud fra et arbejdskraftsynspunkter, at man bedre forstår realiteterne bag ved planerne.

Myrdal arbejder med tre sektorer, som han analyse- 
rer, det traditionelle landbrug, håndværk og den mindre industri og industrien. Han er overbevist om at den afgørende kamp for udvikling må stå pá landet. Når man tager landbrugssektorens størrelse $i$ betragtning og samtidig gør sig den kæmpemæsige befolkningstilvækst klart, er det helt indlysende, at industrien, selv hvis man forudsatter en meget stark stigningstakt her, ikke engang er i stand til at optage befolkningstilvæksten $i$ de forste mange ar. Det er altså på landet slaget skal stå.

Myrdal har nogle virkelig glimrende analyser af forholdene på landet, f.eks. af arbejdshæmmende institutioner så som kastevæsenet og forpagtningssystemet, især "share-croppingsystemet". Klimaet og den dårlige ernærings indflydelse på arbejdsindsatsen behandles også.

I modsatning til andre vestlige okonomer finder Myrdal, at maginalproduktet ved landbruget er storre end nul. De forstnæunte har altid găet ud fra, at det, det drejer sig om, er at skaffe nye arbejdspladser, medens Myrdal påviser, at meget ville vare nået bare med en oget arbejdsindsats pá de enkelte brug. Myrdal kalder denne produktionsform, hvor der er et hojt mand/land forhold, men en ringe indsats af arbejde, arbejdsekstensiv. Dette skyldes, finder Myrdal, institutionernes form og befolkningens holdning til manuelt arbejde. Den kendsgerning, at det sydasiatiske landbrug er arbejdsekstensivt, og at der stadig er nogle muligheder for at inddrage ny jord under dyrkning, ser Myrdal som nogle af de fa lyspunkter.

Herefter analyserer Myrdal flere politiske alternativer. Efter en diskussion af tvangskollektivisering og jordreform med mere, når han frem til at anbefale en form for kapitalistisk landbrug, nemlig incitamenter til de driftige og initiativrige landmænd. Man skulle tro, at Myrdal med sine værdipræmisser ville have foretrukket en jordreform-løsning. Tidspunktet er forpasset, hævder han.

sidste bind beskaftiger sig indgáende med sundhed og undervisning. 


\section{Konklusion}

Myrdal ser meget sort på Sydasiens udviklingsmuligheder. Det afgarende og evigt tilbagevendende er, at institutioner og holdninger ma ændres. Dette kræver en virkelig stærk politisk organisation, og den finder Myrdal ingen steder i sydasien. Hyordan en stærk politisk organisation skabes, kommer Myrdal ikke ind pa. Mange konklusioner synes at forudsætte en politisk revolution. Men Myrdal er intetsteds fortaler for en sadan. Han taler kun om en okonomisk og social revolution.

\section{Andre anmeldelser:}

T.J. Byres,

N.J. Demerath,

C. Geertz,

J. Grossholz,

Ib Jorgensen,

Lars Rudebeck,
Asian Review vol. $2 \mathrm{nr} .3$, april 69 , p. $177-89$

"Thor, Adam Smith, Marx - and Myrdal". Amer.sociol.Review, aug. 68, p. 654-55.

Encounter vol. 33, juli 69, p. 26-34. "Myrdal's Mythology, Modernism and the Third World".

Amer.Polit.sci.Review, dec. 68, p.1278-80.

Acta Sociologica 12 (3) 69, p. 159-61.

Häften för kritiska Studier 3, 1970, p. 19-3o og forts. p. 47. 